\title{
Well Perioperative Glycemic Control Improves Outcomes in Neonates With Surgical Necrotizing Enterocolitis in a Tertiary Referral Center: a Retrospective Study
}

Nan Guo

Shengjing Hospital of China Medical University https://orcid.org/0000-0003-2021-6784

Haiyin Ji

Shengjing Hospital of China Medical University

Dongyi Tong

Shengjing Hospital of China Medical University

Jiaxin Yao

Shengjing Hospital of China Medical University

Ping Zhao ( $\nabla$ zhaoping_sj@163.com )

https://orcid.org/0000-0001-6392-5391

\section{Research}

Keywords: hypoglycemia, hyperglycemia, neonates, NEC, LOS, glucose variability

Posted Date: August 11th, 2020

DOI: https://doi.org/10.21203/rs.3.rs-54813/v1

License: (1) (1) This work is licensed under a Creative Commons Attribution 4.0 International License. Read Full License 


\section{Abstract}

Background: Necrotizing enterocolitis (NEC) is one of the most common and devastating diseases that occurs in neonates, and often requires surgical intervention. Hyperglycemia or hypoglycemia can easily occur in newborns, due to their metabolic immaturity. It remains unknown how factors associated with anesthesia especially perioperative glucose level affect the surgical outcomes of neonates with NEC. In this retrospective observational study, we analyzed the risk factors associated with prolonged hospitalization among neonates who received surgical treatment for necrotizing enterocolitis.

Methods: From January 2016 to October 2019, a total of 204 infants with a gestational age of 28 weeks to 40 weeks underwent open surgery for NEC at Shengjing Hospital of China Medical University. Among those infants, 111 patients were assigned to the well glycemic control group and 93 patients were assigned to the poor glycemic control group. The primary study outcome was the length of postoperative hospital stay. Risk factors that may affect surgical outcomes were collected and analyzed via multivariate logistic regression to determine their association with postoperative hospital stay.

Results: A multivariate logistic regression analysis showed that high preoperative weight $(\mathrm{OR}=0.995$, $95 \% \mathrm{Cl}=0.992-0.997, p<0.001)$ and well glycemic control $(\mathrm{OR}=0.129,95 \% \mathrm{Cl}=0.031-0.535, \mathrm{p}=0.005)$ were independent protective factors for prolonged hospital stay, whereas long duration of endotracheal intubation in $\mathrm{NICU}(\mathrm{OR}=1.239,95 \% \mathrm{Cl}=1.016-1.512, \mathrm{p}=0.035)$ and long days of antibiotics use $(\mathrm{OR}=1.421,95 \% \mathrm{Cl}=1.233-1.637, \mathrm{p}<0.001)$ were independent risk factors for prolonged hospital stay. Patients with perioperative blood glucose control within the prespecified range $(47-150 \mathrm{mg} / \mathrm{dL})$ had shorter postoperative hospital stays than those with perioperative blood glucose measurements outside those limits $(22[18,26]$ vs $29[24.5,36.5]$ days, $p<0.001)$.

Conclusions: Glucose levels outside a pre-specified range were an independent risk factor for a prolonged hospital stay in a population of neonates who underwent surgical repair for NEC.

\section{Introduction}

Necrotizing enterocolitis (NEC) is one of the most common and devastating gastrointestinal inflammatory diseases that occurs in the newborn. Its mortality rate can be up to $30 \%$, and the afflicted infants often require surgery. ${ }^{1,2} \mathrm{NEC}$ is characterized by partial or full thickness intestinal ischemia, usually in the terminal ileum, but may involve the entire bowel. ${ }^{3}$ The known risk factors for NEC include prematurity, formula feeding, and neonatal stress. The initial treatments for NEC include fluid infusion, ventilator support, antibiotic therapy, and other non-surgical methods. However, progressive NEC is treated by the surgical installation of peritoneal drains, bowel resection, and creation of an ostomy. ${ }^{4}$ The high metabolic rate, low glycogen storage rate, and impaired gluconeogenesis and ketogenesis in neonates especially in preterm babies place them at a higher risk for hypoglycemia, which may be associated with brain injury. 5,6 Under stress, derangements in glucose homeostasis may lead not only to hypoglycemia but may also manifest in hyperglycemia especially in the setting of glucose infusions exceeding their normal glucose turnover rate due to an immature response to pathoglycemia. Furthermore, premature infants are more 
likely to display absolute or relative insulin deficiency or insulin resistance. Hyperglycemia has been identified as a risk factor for poor wound healing and surgical site infections, which may cause early death and morbidity, and was especially related to intracranial hemorrhage in extremely low birth weight infants. ${ }^{7-}$

${ }^{9}$ The additional stress of surgery and anesthesia may exacerbate already deranged glucose homeostasis associated with bowel ischemia. Glucose variability is the extent of blood glucose fluctuations which occur within a specified period. Hence, perioperative glucose oscillations are common in neonates, and careful blood glucose monitoring and management is crucial for neonates undergoing surgery. Less is known of the normal range of glucose for neonates. A cohort study by Mckinlay found that neonatal hypoglycemia was not associated with an adverse neurologic outcome when treatment was provided to maintain a blood glucose concentration of at least $47 \mathrm{mg} / \mathrm{dl} .{ }^{10}$ Hays suggested that glucose value $>150 \mathrm{mg} / \mathrm{dL}$ is a risk factor for early death and morbidity in extremely low birth-weight infants and will increase the risk of cerebral hemorrhage. ${ }^{11}$ However, a few study shows that tight glucose control of neonates may lead to high risk of hypoglycemia which was more severe and maintaining glucose $<150 \mathrm{mg} / \mathrm{dl}$ has not consistently demonstrated improvement in outcomes. ${ }^{12,13}$. Few studies focused on blood glucose level and glucose variability on the effect of prognosis in critical ill neonates especially in perioperative period. We have observed a number of neonates who suffered from hypoglycemia, hyperglycemia and glucose variability in our care. This retrospective study was designed to assess the association between perioperative blood glucose control within a range of $47-150 \mathrm{mg} / \mathrm{dL}$ and the length of postoperative hospital stay among neonates who received surgical treatment for necrotizing enterocolitis.

\section{Materials And Methods}

\section{Ethics approval}

The study protocol was approved by the Clinical Research Ethics Committee of China Medical University, Shengjing Hospital (2018PS515K). The initial IRB approval is dated November 22, 2018. Due to the retrospective nature of this study, and the fact that all pertinent data had been obtained from patient medical records, the local Ethics Committee agreed that the study did not require written informed consents.

\section{Patients and inclusion/exclusion criteria}

Potential participants were patients who had undergone open abdominal surgery for necrotizing enterocolitis, as diagnosed by a preoperative X-ray assessment, clinical symptoms, an intraoperative diagnosis, and then subsequently confirmed by a surgeon at the China Medical University from January 2016 to October 2019. All patients met the stage $\triangle$ NEC surgical criterion: medical therapy was not successful for 48 hours prior to surgery. ${ }^{14}$ Patients who met any of the following criteria were excluded from the study: (1) gestational age < 28 weeks; (2) surgery was performed in a manner other than open abdominal bowel resection and ostomy; (3) fewer than 5 glucose measurements in the perioperative period; (4) NEC was accompanied by a severe congenital heart disease, or other significant co-morbidity; (5) refused treatment before meeting the clinical cure standard or died after surgery. Infants with a tiny-to-small patent ductus arteriosus or patent foramen ovale were not considered to have congenital heart disease and 
were therefore included. ${ }^{15}$ Among 309 patients who underwent open abdominal surgery from January 2016 to October 2019, a total of 204 patients met the study's inclusion/exclusion criteria. Those patients were divided into two groups according to their perioperative blood glucose level. Patients with a perioperative blood glucose concentration in the range of $47-150 \mathrm{mg} / \mathrm{dL}$ were designated as well glycemic control. Any two measurements (consecutive or non-consecutive) of blood glucose made 24 hours before, during or after the surgery, and whose values were not within the pre-specified range, were considered to indicate poor perioperative glycemic control. As a result, 111 patients were assigned to the well glycemic control group and 93 patients were assigned to the poor glycemic control group. All blood glucose values were determined by arterial puncture or the finger/heal stick blood glucose test. Prior to surgery, all newborns with NEC underwent the same routine treatment, which included bowel rest, intravenous nutrition, parenteral antibiotics, nasogastric suction, and cardio-respiratory support as necessary.

\section{Anesthesia, surgery, and perioperative management}

All patients received general anesthesia via endotracheal intubation. Anesthesia was induced with sevoflurane $(6-8 \%)$ and maintained with sevoflurane $(2.5-3 \%)$ or sevoflurane combined with remifentanil $(0.05-0.2 \mu \mathrm{g} / \mathrm{kg} / \mathrm{min})$ and inotropic agents when necessary. Intraoperative fluid maintenance consisted of normal saline solution or $1 \%$ or $5 \%$ glucose-containing solution to achieve a plasma glucose level of 47-150 $\mathrm{mg} / \mathrm{dL} .{ }^{16}$ Insulin therapy (0.01-0.2 $\mathrm{U} /(\mathrm{kg} \cdot \mathrm{h})$ was given to patients whose hyperglycemia persisted despite the decrease of glucose infusion. Patients were actively warmed throughout surgery. Bowel resection and ostomy were performed routinely. Postoperative length of stay (LOS) were recorded according to the hospital's discharge chart. All procedures were performed by qualified surgeons and anesthesiologists who each had $>10$ years of clinical experience.

\section{Data collection}

Data were collected from the hospital's medical record system, and eligible patients were identified via the study's inclusion/exclusion criteria. Demographic characteristics (gender, gestational age, gestational weight, type of delivery), pre-operative information (post-conceptual age, use of inotropic agents, glucose delivery rate(GDR), weight before surgery, hemoglobin, heart rate, blood pressure, albumin, creatinine, CRP, American Society of Anesthesiologists classification, entry into the operating room (O.R.) with an endotracheal tube), intraoperative information (surgery duration, anesthesia duration, blood loss, blood transfusion, fluid balance, hemodynamic fluctuations, extubated time), and postoperative information (hemoglobin, albumin, occurrence of complications, antibiotics use, length of hospital stay, standard deviation of blood glucose) were all included in the patient records. The primary outcome of the study was the length of postoperative hospital stay, which is a comprehensive indicator reflecting the prognosis of neonatal NEC.

\section{Statistical analysis}

Numeric data with a normal distribution were compared using the independent samples $t$ test; numeric data with a non-normal distribution were compared using the Mann-Whitney $U$ test; categorical data were compared by using the chi-square test or Fisher's exact test. To identify independent risk factors for 
postoperative hospital stay, variables with a $p$-value $\leq 0.1$ in univariate analyses were included in a multivariate logistic model. A two-sided $p$-value $<0.05$ was considered to be statistically significant. All statistical analyses were performed using IBM SPSS Statistics for Windows, Version 20.0 software (IBM Corp., Armonk, NY, USA).

\section{Results}

\section{Patients}

204 eligible admissions generated 1264 glucose values (median: $108 \mathrm{mg} / \mathrm{dL}$; range: $34-245 \mathrm{mg} / \mathrm{dL}$ ). A total of 309 infants with NEC underwent surgery during the study period. Among those patients, 105 were excluded for the following reasons: 20 were of age < 28 weeks; 3 patients received laparoscopic surgery; 9 patients were complicated with severe congenital heart disease; 22 patients did not receive bowel resection and anastomosis; 18 patients refused treatment during surgery or transferred after surgery; 26 patients had fewer than 5 glucose measurements; 7 patients had insufficient data. Consequently, data from 204 patients was collected for analysis (Figure 1).

The baseline and perioperative data are presented in Table 1 and outcome variables are presented in Table 2 .

Our analysis showed that patients in the well glycemic control group and poor glycemic control glucose group had similar values for clinical parameters such as gender, gestational age, gestational weight, ASA, preoperative CRP, glucose delivery rate $(p>0.05)$ (Table 1$)$. The median length of postoperative hospital stay was shorter among patients in well glycemic control group than among patients in poor glycemic control group $(22[18,26]$ vs $29[24.5,36.5]$ days, $p<0.001)$. Furthermore, postoperative antibiotics use $(14[10,20]$ vs $20[15.5,24.5)]$ days, $p<0.001)$ was shorter and the incidence of complications was lower $(24.3 \%$ [27/111 patients] vs $61.3 \%$ [57/93 patients], $p<0.001)$ in well glycemic control group when compared with the poor glycemic control group.(Table 2)

\section{Risk factor analysis}

In order to investigate the risk factors for a prolonged postoperative hospital stay, we compared the clinical characteristics of patients with a $\leq 28$ day hospital stay with those of patients with a $>28$ day hospital stay (Tables 3,4). A univariate logistic regression analysis identified 14 factors that were associated with the length of a postoperative hospital stay ( $\leq 0.1$ ); those factors included gestational age, gestational week, preoperative creatinine, post-conceptual age, entry into the operating room (O.R.) with an endotracheal tube, preoperative weight, ASA classification, blood loss, hemodynamic fluctuations, duration of tracheal extubation, postoperative antibiotics use, well glycemic control, SD of blood glucose and occurrence of complication. After excluding gestational age (with post-conceptual age) and gestational weight (with preoperative weight) because of collinearity, 12 factors were included in the subsequent multivariate logistic regression analysis. That analysis identified long duration of endotracheal intubation in $\mathrm{NICU}(\mathrm{OR}=1.239$, $95 \% \mathrm{Cl}=1.016-1.512, \mathrm{p}=0.035)$ and long days of antibiotics use $(\mathrm{OR}=1.421,95 \% \mathrm{Cl}=1.233-1.637, \mathrm{p}<0.001)$ as risk factors for a prolonged postoperative hospital stay, whereas a high preoperative weight $(\mathrm{OR}=0.995$, 
$95 \% \mathrm{Cl}=0.992-0.997, \mathrm{p}<0.001$ ), well glycemic control(maintenance of perioperative blood glucose concentrations in the range of 47 to $150 \mathrm{mg} / \mathrm{dL})(\mathrm{OR}=0.129,95 \% \mathrm{Cl}=0.031-0.535, \mathrm{p}=0.005)$ were identified as factors that protected against a prolonged postoperative hospital stay (Table 5).

\section{Discussion}

Results of this retrospective study showed that among patients undergoing open abdominal surgery for NEC, maintaining perioperative blood glucose level in a range of 47 to $150 \mathrm{mg} / \mathrm{dL}$ was associated with a shorter postoperative hospital stay. Long duration of tracheal extubation in NICU, long days of antibiotics use and low gestational weight are risk factors for a prolonged postoperative hospital.

Long-term hypoglycemia can lead to profound adverse neurodevelopmental consequences, poor feeding and delays in growth and development, all of which can prolong a patient's postoperative hospital stay. ${ }^{17}$ Duckrow ${ }^{18}$ found that regional cerebral blood flow decreases during chronic and acute hyperglycemia which can cause cerebral hypoxia and has been described as an important risk factor for production of neurologic damage ${ }^{19}$. A study by Hay ${ }^{11}$ suggested that prolonged hyperglycemia might have a deleterious effect on lung development, perhaps by inducing hyperosmolarity or triggering oxidative stress. It is well established that the incidence of bronchopulmonary dysplasia increases with decreasing birth weight, and the resultant decreased growth rate and increased oxygen requirements lengthen an infant's postoperative hospital stay. We has already known that low gestational age is a risk factor for NEC progression. ${ }^{20}$, ${ }^{21}$ Another study found that newborns with a lower birth weight and an early stage of NEC were more likely to develop severe NEC. ${ }^{22}$ Low perioperative weight is considered to be a type of immature development and to reflect a low adaptive response to stress caused by surgery and anesthesia. Entering into the operation room with endotracheal tube reflects respiratory failure before surgery and postoperative longer days of antibiotics use means severe infection and therefore obviously prolonged neonates' hospitalization. Our findings in the present study are consistent with those in previous studies. Hence, perioperative glycemic control, preoperative weight, Enter into the operation with endotracheal tube and antibiotics use all have impact on postoperative hospital stay, and also the prognosis of neonates with NEC.

In our study, perioperative glucose monitoring showed that episodes of intraoperative low glucose concentration were more common in poor glycemic control group, whose preoperative glucose delivery rate were lower than that in well glycemic control group though not significant $(6.79 \pm 1.17 \mathrm{mg} / \mathrm{kg} / \mathrm{min}$ vs $7.11 \pm$ $1.55 \mathrm{mg} / \mathrm{kg} / \mathrm{min}, \mathrm{p}>0.05)$. And some of them occurred persistent hyperglycemia during post-operative period(24 hours after surgery). This finding may possibly be due to a decreased responsiveness of $\beta$-cells in premature pancreas of preterm neonates. Under stress, derangements in glucose homeostasis may lead to hyperglycemia when glucose infusions exceeding their normal glucose turnover rate due to an immature response to pathoglycemia. Because no standard transfusion protocol was used, our hospital used either $1 \%$ or $5 \%$ glucose-containing solution or normal saline through the infusion pump to maintain fluid and glucose homeostasis during surgery. However, the hypoglycemia could not be rapidly or excessively corrected, because a rapid correction of hypoglycemia has been reported to be associated with a poor outcome. Studies in an animal model have also demonstrated that higher blood glucose concentrations 
during recovery from hypoglycemia can worsen neurologic damage, at least in part because of an increased generation of reactive oxygen species. ${ }^{23,24}$ Perioperative glycemic fluctuations were more common in poor glycemic control group (Standard deviation of blood glucose: $43.78 \pm 7.91 \mathrm{mg} / \mathrm{dL}$ vs $31.01 \pm 8.05 \mathrm{mg} / \mathrm{dL}$, $\mathrm{p}$ $<0.001)$. Patients whose postoperative hospital stay longer than 28 days after had higher SD of blood glucose levels than control $(40.26 \pm 10.17 \mathrm{mg} / \mathrm{dL}$ vs $34.88 \pm 9.73 \mathrm{mg} / \mathrm{dL}, \mathrm{p}<0.001)$. Glycemic fluctuation can increase the serum levels of chronic inflammatory marker (high-sensitivity C-reactive protein) and lead to an overproduction of free radicals then inducing oxidative stress. ${ }^{25}$ Fluctuation of blood glucose levels increased hospital stay via influencing wound healing and infection. A large meta analysis looking at over 4000 patients from six studies showed that tight glycemic control does not improve mortality or outcome other than dialysis needs in pediatric intensive care units. The main difference of our study is that our study focused on perioperative period. Perioperative hyperglycemia might be considered as a marker of high stress level. And due to the derangements in glucose homeostasis in critical ill neonates, many of them occurred hyperglycemia after treatment of hypoglycemia. Evans believed that hyperglycemia in the perioperative period is associated with increased morbidity, decreased survival, and increased resource utilization $^{26}$. Our study is consistent with that. Trying to avoid perioperative hypoglycemia, hyperglycemia and glucose variability may help to optimize patients' outcome around NEC surgery. It's not inconsistent with the previous study which demonstrated that tight glucose control does not result in a decrease in hospital mortality in pediatric intensive care units ${ }^{27}$.

Perioperative abundant nutrition is beneficial to attenuate stress response which improve surgical outcome. Low glycogen storage rate, impaired gluconeogenesis and ketogenesis in neonates make them more likely to suffer from hypoglycemia. Carbohydrate loading is necessary to meet the increased energy demands of stressed patients. Several studies focused on perioperative glucose-containing solution. European guideline suggested intraoperative $1-2.5 \%$ balanced glucose-containing solution is safe to prevent hypoglycemia and hyperglycemia, but need careful monitoring and management. ${ }^{28}$ Our study found that pathoglycemia and glycemic variability were common in critically ill neonates and decreasing glucose fluctuation during hospitalization for surgery is important. Little information is available to guide clinicians in how glycemic variability can be reduced but careful glucose monitoring and management may help. Due to deranged glucose homeostasis of neonates and the painful nature of capillary or venous blood testing, noninvasive continuous glucose monitoring may be a good strategy for favourable perioperative blood glucose control. Additional randomized trials are needed to settle the debate about what constitutes a normal neonatal glucose value and the best method of perioperative glucose infusion. Furthermore, new methods for the careful monitoring and control of perioperative glucose levels need to be developed. No definite threshold exists for a normal neonatal blood glucose concentration, mainly because of a lack of data concerning the impact of blood glucose concentrations on the short- and long-term clinical outcomes of neonates.

Our study has several limitations that should be mentioned. Its main limitation is the potential for bias in the inclusion/exclusion criteria due to the study's retrospective design. Glucose derangements might be a marker of severity of illness, which prejudge the outcome, although there is no statistical significance in gestational age, gestational weight, preoperative CRP and ASA between two groups. Second, although a blood glucose concentration of $47 \mathrm{mg} / \mathrm{dL}$ is well-accepted as the threshold for treating hypoglycemia in 
newborns, there is no evidence that intervention at that threshold is safe or effective. ${ }^{29}$ However, McKinlay ${ }^{30}$ found in his prospective study that treatment of neonatal hypoglycemia starting at a threshold of $47 \mathrm{mg}$ of glucose per deciliter was not associated with any subsequent adverse neurodevelopmental outcomes at 2 years. At present, there is no reliable tool that can be used to assess the neurologic state related to a blood glucose concentration in infants. Therefore, clinicians need a pragmatic threshold that indicates when to provide treatment needed to ensure an adequate supply of metabolic fuel for the developing brain during the neonatal transition period. Meanwhile, adverse outcomes have been reported at blood glucose levels > $150 \mathrm{mg} / \mathrm{dL}$, and the threshold for significant neonatal hyperglycemia remains unclear. In this study, we regarded a perioperative glucose concentration in the range of 47 to $150 \mathrm{mg} / \mathrm{dL}$ as well glycemic control; however, that definition may not be sufficiently precise. Third, the intervals and frequency of blood glucose tests ( 24 hours before, during and 24 hours after surgery) were not the same for each patient, although each patient was measured for blood glucose at least five times in total. A few patients may have been mistakenly allocated to the well glycemic control group because an abnormal glucose value was not detected in time due to observation bias. Arterial punctures for blood gas analysis are difficult to perform in all infants in China (similar to any developing country) during surgery. Therefore, various biochemical parameters, such as electrolyte levels, were not included in our analysis because the data were unavailable. We didn't include patients under 28 weeks because few infants delivered at this gestational age range underwent NEC surgery in our hospital and meanwhile these few infants may cause obvious bias to the LOS due to their extremely immature development. In addition to the retrospective nature of our study, other limitations also exist. As a single-center study, our results should not be extrapolated to patients treated at other centers.

Nevertheless, our results showed that perioperative blood glucose control is necessary for the optimal treatment of neonatal NEC, and has a positive impact on the patient's postoperative hospital stay and overall prognosis. This study was undertaken to gain a better understanding of glucose monitoring and control in the perioperative period and to broaden the understanding of how hypoglycemia and hyperglycemia, as well as glucose variability, are associated with hospital length of stay in critical ill population. However, these observational findings require further verification in randomized clinical trials.

\section{Conclusions}

Glucose levels outside of a prespecified range were an independent risk factor for a prolonged hospital stay in a population of neonates undergoing surgical repair for NEC. Careful perioperative blood glucose monitoring and control may be crucial for achieving better outcomes for neonates with NEC.

\section{Declarations}

\section{Ethics approval and consent to participate}

The study protocol was approved by the Clinical Research Ethics Committee of China Medical University, Shengjing Hospital (2018PS515K). The initial IRB approval is dated November 22, 2018. Due to the 
retrospective nature of this study, and the fact that all pertinent data had been obtained from patient medical records, the local Ethics Committee agreed that the study did not require written informed consents.

\section{Consent for publication}

Not applicable

\section{Availability of data and materials}

All data generated or analysed during this study are included in this published article

\section{Competing interests}

The authors declare that they have no competing interests

\section{Funding Sources}

This work was supported by the National Nature Science Foundation of China (No. 81671311, No.81870838).

\section{Authors' contributions}

All authors made substantial contributions to the study and met the criteria for authorship defined in the author instructions: NG contributed to acquisition, analysis and interpretation of data, and drafting of the manuscript; HJ contributed to acquisition and analysis of data; DT contributed to the collection of data; JY contributed to the collection of data. PZ: supervised the project, analyzed data and wrote manuscript. All authors participated manuscript preparation and approved the final manuscript.

\section{Acknowledgements}

We thank Dr Randall Flick for his invaluable revision of this manuscript.

\section{References}

1. Neu J. Necrotizing enterocolitis: the mystery goes on. Neonatology. 2014; 106:289-95.

2. Neu J, Walker WA. Necrotizing enterocolitis. N Engl J Med. 2011; 364:255-64.

3. Zani A, Pierro A. Necrotizing enterocolitis: controversies and challenges. F1000Res. 2015; 4.

4. Robinson JR, Rellinger EJ, Hatch LD, Weitkamp JH, Speck KE, Danko M, et al. Surgical necrotizing enterocolitis. Semin Perinatol. 2017; 41:70-9.

5. Goode RH, Rettiganti M, Li J, Lyle RE, Whiteside-Mansell L, Barrett KW, et al. Developmental Outcomes of Preterm Infants With Neonatal Hypoglycemia. Pediatrics. 2016; 138.

6. Tam EW, Haeusslein LA, Bonifacio SL, Glass HC, Rogers EE, Jeremy RJ, et al. Hypoglycemia is associated with increased risk for brain injury and adverse neurodevelopmental outcome in neonates at risk for encephalopathy. J Pediatr. 2012; 161:88-93. 
7. Srinivasan V, Spinella PC, Drott HR, Roth CL, Helfaer MA, Nadkarni V. Association of timing, duration, and intensity of hyperglycemia with intensive care unit mortality in critically ill children. Pediatr Crit Care Med. 2004; 5:329-36.

8. Bochicchio GV, Sung J, Joshi M, Bochicchio K, Johnson SB, Meyer W, et al. Persistent hyperglycemia is predictive of outcome in critically ill trauma patients. J Trauma. 2005; 58:921-4.

9. Schuster JM, Rechtine G, Norvell DC, Dettori JR. The influence of perioperative risk factors and therapeutic interventions on infection rates after spine surgery: a systematic review. Spine. 2010; 35:S125-37.

10. McKinlay CJ, Alsweiler JM, Ansell JM, Anstice NS, Chase JG, Gamble GD, et al. Neonatal Glycemia and Neurodevelopmental Outcomes at 2 Years. N Engl J Med. 2015; 373:1507-18.

11. Hays SP, Smith EO, Sunehag AL. Hyperglycemia is a risk factor for early death and morbidity in extremely low birth-weight infants. Pediatrics. 2006; 118:1811-8.

12. Beardsall K, Vanhaesebrouck S, Ogilvy-Stuart AL, Vanhole $C$, Palmer CR, van Weissenbruch $M$, et al. Early insulin therapy in very-low-birth-weight infants. N Engl J Med. 2008; 359:1873-84.

13. Huang IC, Wang PW, Liu RT, Tung SC, Chen JF, Kuo MC, et al. The influence of self-monitoring blood glucose frequency on the oscillation of hemoglobin A1c and chronic complications. Chang Gung Med J. 2012; 35:46-53.

14. Walsh MC, Kliegman RM. Necrotizing enterocolitis: treatment based on staging criteria. Pediatr Clin North Am. 1986; 33:179-201.

15. Pickard SS, Feinstein JA, Popat RA, Huang L, Dutta S. Short- and long-term outcomes of necrotizing enterocolitis in infants with congenital heart disease. Pediatrics. 2009; 123:e901-6.

16. Adamkin DH. Neonatal hypoglycemia. Semin Fetal Neonatal Med. 2017; 22:36-41.

17. Dassios T, Greenough A, Leontiadi S, Hickey A, Kametas N. Admissions for hypoglycaemia after 35 ? weeks of gestation: perinatal predictors of cost of stay. The Journal of Maternal-Fetal \& Neonatal Medicine. 2018; 32:448-54.

18. Duckrow RB, Beard DC, Brennan RW. Regional cerebral blood flow decreases during chronic and acute hyperglycemia. Stroke. 1987; 18:52-8.

19. Sieber FE, Smith DS, Traystman RJ, Wollman H. Glucose: a reevaluation of its intraoperative use. Anesthesiology. 1987; 67:72-81.

20. Samuels N, van de Graaf RA, de Jonge RCJ, Reiss IKM, Vermeulen MJ. Risk factors for necrotizing enterocolitis in neonates: a systematic review of prognostic studies. BMC Pediatr. 2017; 17:105.

21. Luo L, Dong W, Zhang L, Zhai X, Li Q, Lei X. Correlative Factors of the Deterioration of Necrotizing Enterocolitis in Small for Gestational Age Newborns. Sci Rep. 2018; 8:13.

22. Miner CA, Fullmer S, Eggett DL, Christensen RD. Factors affecting the severity of necrotizing enterocolitis. J Matern Fetal Neonatal Med. 2013; 26:1715-9.

23. McKinlay CJD, Chase JG, Dickson J, Harris DL, Alsweiler JM, Harding JE. Continuous glucose monitoring in neonates: a review. Matern Health Neonatol Perinatol. 2017; 3:18. 
24. Suh SW, Gum ET, Hamby AM, Chan PH, Swanson RA. Hypoglycemic neuronal death is triggered by glucose reperfusion and activation of neuronal NADPH oxidase. J Clin Invest. 2007; 117:910-8.

25. Monnier L, Mas E, Ginet C, Michel F, Villon L, Cristol JP, et al. Activation of oxidative stress by acute glucose fluctuations compared with sustained chronic hyperglycemia in patients with type 2 diabetes. JAMA. 2006; 295:1681-7.

26. Evans CH, Lee J, Ruhlman MK. Optimal glucose management in the perioperative period. Surg Clin North Am. 2015; 95:337-54.

27. Chen L, Li T, Fang F, Zhang Y, Faramand A. Tight glycemic control in critically ill pediatric patients: a systematic review and meta-analysis. Crit Care. 2018; 22:57.

28. Sumpelmann R, Becke K, Crean P, Johr M, Lonnqvist PA, Strauss JM, et al. European consensus statement for intraoperative fluid therapy in children. Eur $J$ Anaesthesiol. 2011; 28:637-9.

29. Adamkin DH. Postnatal glucose homeostasis in late-preterm and term infants. Pediatrics. 2011; 127:575-9.

30. Harris DL, Weston PJ, Williams CE, Pleasants AB, Battin MR, Spooner CG, et al. Cot-side electroencephalography monitoring is not clinically useful in the detection of mild neonatal hypoglycemia. J Pediatr. 2011; 159:755-60.e1.

\section{Tables}


Table 1

Pre-, intra- and postoperative variables in the study population

\begin{tabular}{|lllll|}
\hline & Totally & WGCG & PGCG & $\begin{array}{c}\text { P } \\
\text { value }\end{array}$ \\
\hline Variable & $(\mathbf{n}=\mathbf{2 0 4})$ & $(\mathbf{n = 1 1 1})$ & $(\mathbf{n = 9 3 )}$ & \\
\hline Gender & & & & 0.261 \\
\hline Male & $132(64.7 \%)$ & $68(61.3 \%)$ & $64(68.8 \%)$ & \\
\hline Female & $72(35.3 \%)$ & $43(38.7 \%)$ & $29(31.2 \%)$ & \\
\hline Gestational age(weeks) & $31.91 \pm 2.63$ & $32.21 \pm 2.54$ & $31.56 \pm 2.71$ & 0.077 \\
\hline Gestational weight(g) & $1725.15 \pm$ & $1795.16 \pm$ & $1643.78 \pm$ & 0.05 \\
\hline Type of delivery & 550.03 & 567.22 & 519.86 & \\
\hline caesarean delivery & & & & 0.345 \\
\hline natural labor & $147(72.1 \%)$ & $83(74.8 \%)$ & $64(68.8 \%)$ & \\
\hline Post-conceptual age $(\mathrm{weeks})$ & $57(29.9 \%)$ & $28(25.2 \%)$ & $29(31.2 \%)$ & \\
\hline Preoperative weight(g) & $36.01 \pm 3.65$ & $36.50 \pm 4.12$ & $35.41 \pm 2.91$ & 0.028 \\
\hline Preoperative hemoglobin(g/l) & $2003.02 \pm$ & $2054.14 \pm$ & $1942.02 \pm$ & 0.118 \\
\hline Preoperative albumin (g/l) & 510.05 & 563.57 & 432.86 & \\
\hline Preoperative creatinine (g/l) & $115.35 \pm 22.80$ & $114.59 \pm 22.46$ & $116.27 \pm 23.30$ & 0.601 \\
\hline Preoperative CRP(mg/l) & $29.46 \pm 4.65$ & $29.29 \pm 4.93$ & $29.67 \pm 4.31$ & 0.557 \\
\hline Preoperative SBP (mmHg) & $47.85 \pm 15.67$ & $45.84 \pm 16.17$ & $50.24 \pm 14.77$ & 0.045 \\
\hline Preoperative DBP (mmHg) & $29.9(6.70,78.83)$ & $32.1(7.12,75.6)$ & $28.9(6.36,83.1)$ & \\
\hline & $65.36 \pm 11.46$ & $65.66 \pm 12.06$ & $65.00 \pm 10.76$ & 0.684 \\
\hline & $35.06 \pm 8.65$ & $35.19 \pm 9.56$ & $34.90 \pm 7.48$ & 0.815 \\
\hline & & & & \\
\hline
\end{tabular}

WGCG = Well Glycemic Control Group. PGCG = Poor Glycemic Control Group. SBP = Systolic Blood Pressure. $\mathrm{DBP}=$ Diastolic Blood Pressure. $\mathrm{HR}=$ Heart Rate.

O.R. = Operating Room. ASA = American Society of Anesthesiologists. ICU = Intensive Care Unit. GDR = Glucose Delivery Rate. $\mathrm{SD}=$ Standard Deviation. $\mathrm{BG}=$ Blood Glucose

Data are presented as the mean \pm standard deviation, number of patients, or median (interquartile range), unless otherwise indicated.

a defined when having met any of the following criteria: systolic pressure $\geq 100$ or $\leq 40 \mathrm{mmHg}$, or increased $>30 \%$ above baseline; heart rate $\geq 180$ or $\leq 100 \mathrm{bpm}$.

$\mathrm{b}$ the blood products infused included packed red blood cells, blood plasma, and platelets.

${ }^{c}$ some of the patients were extubated in the O.R. and some were extubated in the NICU after surgery. 


\begin{tabular}{|c|c|c|c|c|}
\hline & Totally & WGCG & PGCG & $\begin{array}{l}P \\
\text { value }\end{array}$ \\
\hline Preoperative HR (bmp) & $146.35 \pm 12.29$ & $146.4 \pm 14.06$ & $146.3 \pm 9.86$ & 0.955 \\
\hline Preoperative inotrope drugs & & & & 0.781 \\
\hline Yes & $39(19.1 \%)$ & $22(19.8 \%)$ & $17(18.3 \%)$ & \\
\hline No & $165(80.9 \%)$ & $89(80.2 \%)$ & $76(81.7 \%)$ & \\
\hline \multicolumn{5}{|l|}{ Preoperative nutrition } \\
\hline $\begin{array}{l}\text { GDR one day before } \\
\text { surgery }(\mathrm{mg} / \mathrm{kg} / \mathrm{min})\end{array}$ & $6.83 \pm 0.96$ & $6.90 \pm 1.03$ & $6.74 \pm 0.87$ & 0.226 \\
\hline $\begin{array}{l}\text { GDR on the day of } \\
\text { surgery }(\mathrm{mg} / \mathrm{kg} / \mathrm{min})\end{array}$ & $6.59 \pm 1.19$ & $6.63 \pm 1.30$ & $6.55 \pm 1.05$ & 0.648 \\
\hline ASA classification & & & & 0.371 \\
\hline 2 and 3 & $136(66.7 \%)$ & $77(69.4 \%)$ & $59(63.4 \%)$ & \\
\hline 4 & $68(33.3 \%)$ & $34(30.6 \%)$ & $34(36.6 \%)$ & \\
\hline $\begin{array}{l}\text { Entry into O.R. with endotracheal } \\
\text { tube }\end{array}$ & & & & 0.03 \\
\hline Yes & $80(39.2 \%)$ & $36(32.4 \%)$ & $44(47.3 \%)$ & \\
\hline No & $124(60.8 \%)$ & $75(67.6 \%)$ & $49(52.7 \%)$ & \\
\hline Duration of surgery (mins) & $89.00 \pm 26.87$ & $91.68 \pm 26.18$ & $85.80 \pm 27.46$ & 0.119 \\
\hline Duration of anesthesia (mins) & $107.02 \pm 29.37$ & $111.28 \pm 29.51$ & $101.94 \pm 28.54$ & 0.023 \\
\hline Hemodynamic fluctuation ${ }^{a}$ & & & & 0.219 \\
\hline Yes & $53(26 \%)$ & $25(22.5 \%)$ & $28(30.1 \%)$ & \\
\hline No & $151(74 \%)$ & $86(77.5 \%)$ & $65(69.9 \%)$ & \\
\hline \multicolumn{5}{|c|}{$\begin{array}{l}\text { WGCG = Well Glycemic Control Group. PGCG = Poor Glycemic Control Group. SBP = Systolic Blood } \\
\text { Pressure. DBP = Diastolic Blood Pressure. HR = Heart Rate. }\end{array}$} \\
\hline \multicolumn{5}{|c|}{$\begin{array}{l}\text { O.R. = Operating Room. ASA = American Society of Anesthesiologists. ICU = Intensive Care Unit. GDR = } \\
\text { Glucose Delivery Rate. } S D=\text { Standard Deviation. } B G=\text { Blood Glucose }\end{array}$} \\
\hline \multicolumn{5}{|c|}{$\begin{array}{l}\text { Data are presented as the mean } \pm \text { standard deviation, number of patients, or median (interquartile } \\
\text { range), unless otherwise indicated. }\end{array}$} \\
\hline \multicolumn{5}{|c|}{$\begin{array}{l}\text { a defined when having met any of the following criteria: systolic pressure } \geq 100 \text { or } \leq 40 \mathrm{mmHg} \text {, or } \\
\text { increased }>30 \% \text { above baseline; heart rate } \geq 180 \text { or } \leq 100 \mathrm{bpm} \text {. }\end{array}$} \\
\hline \multicolumn{5}{|c|}{ b the blood products infused included packed red blood cells, blood plasma, and platelets. } \\
\hline
\end{tabular}




\begin{tabular}{|c|c|c|c|c|}
\hline & Totally & WGCG & PGCG & $\begin{array}{l}P \\
\text { value }\end{array}$ \\
\hline Blood loss (ml) & $5(5,10)$ & $5(2,10)$ & $5(5,10)$ & \\
\hline Fluid balance $(\mathrm{ml})$ & $20(18.5,40)$ & $20(20,40)$ & $20(15,40)$ & \\
\hline Perioperative blood transfusion(ml) & $30(0,30)$ & $30(0,30)$ & $25(0,30)$ & \\
\hline Perioperative blood transfusion ${ }^{b}$ & & & & 0.571 \\
\hline Yes & $134(65.7 \%)$ & $71(64 \%)$ & $63(67.7 \%)$ & \\
\hline No & $70(34.3 \%)$ & $40(36 \%)$ & $30(32.3 \%)$ & \\
\hline Postoperative hemoglobin(g/l) & $104.77 \pm 14.43$ & $104.69 \pm 13.14$ & $104.87 \pm 15.91$ & 0.931 \\
\hline Postoperative albumin (g/l) & $35.05 \pm 7.32$ & $35.01 \pm 7.23$ & $35.10 \pm 7.48$ & 0.927 \\
\hline \multicolumn{5}{|l|}{ duration of extubation ${ }^{c}$} \\
\hline time at O.R.(mins) & $15(10,20)$ & $15(10,20)$ & $11.50(7,27.5)$ & \\
\hline time in ICU (days) & $4(3,7)$ & $4(2.75,6)$ & $5(4,8)$ & \\
\hline $\begin{array}{l}\text { GDR one day after } \\
\text { surgery }(\mathrm{mg} / \mathrm{kg} / \mathrm{min})\end{array}$ & $7.06 \pm 0.93$ & $7.15 \pm 1.03$ & $6.96 \pm 0.80$ & 0.121 \\
\hline Glucose value(mg/dL) & $105.29 \pm 16.21$ & $100.45 \pm 14.99$ & $111.07 \pm 15.79$ & $\stackrel{<}{0.001}$ \\
\hline $\mathrm{SD}$ of $\mathrm{BG}(\mathrm{mg} / \mathrm{dL})$ & $36.83 \pm 10.20$ & $31.01 \pm 8.05$ & $43.78 \pm 7.91$ & $\dot{0} 001$ \\
\hline \multicolumn{5}{|c|}{$\begin{array}{l}\text { WGCG = Well Glycemic Control Group. PGCG = Poor Glycemic Control Group. SBP = Systolic Blood } \\
\text { Pressure. DBP = Diastolic Blood Pressure. HR = Heart Rate. }\end{array}$} \\
\hline \multicolumn{5}{|c|}{$\begin{array}{l}\text { O.R. = Operating Room. } \mathrm{ASA}=\text { American Society of Anesthesiologists. } \mathrm{ICU}=\text { Intensive Care Unit. GDR = } \\
\text { Glucose Delivery Rate. } \mathrm{SD}=\text { Standard Deviation. } \mathrm{BG}=\text { Blood Glucose }\end{array}$} \\
\hline \multicolumn{5}{|c|}{$\begin{array}{l}\text { Data are presented as the mean } \pm \text { standard deviation, number of patients, or median (interquartile } \\
\text { range), unless otherwise indicated. }\end{array}$} \\
\hline \multicolumn{5}{|c|}{$\begin{array}{l}\text { a defined when having met any of the following criteria: systolic pressure } \geq 100 \text { or } \leq 40 \mathrm{mmHg} \text {, or } \\
\text { increased }>30 \% \text { above baseline; heart rate } \geq 180 \text { or } \leq 100 \mathrm{bpm} \text {. }\end{array}$} \\
\hline \multicolumn{5}{|c|}{$\mathrm{b}$ the blood products infused included packed red blood cells, blood plasma, and platelets. } \\
\hline
\end{tabular}


Table 2

Postoperative outcomes

\begin{tabular}{|c|c|c|c|c|c|c|}
\hline & Totally & WGCG & PGCG & Statistic & & Significance \\
\hline $\begin{array}{l}\text { Mann- } \\
\text { Whitney U }\end{array}$ & & & & Z & & $\mathrm{p}$ \\
\hline $\begin{array}{l}\text { Antibiotic } \\
\text { days }\end{array}$ & $17(12,22)$ & $14(10,20)$ & $20(15.5,24.5)$ & -5.293 & & $<0.001$ \\
\hline $\begin{array}{l}\text { Postoperative } \\
\text { hospital } \\
\text { stay(days) }\end{array}$ & $25(20,32)$ & $22(18,26)$ & $29(24.5,36.5)$ & -5.34 & & $<0.001$ \\
\hline Chi-Square & & & & $x^{2}$ & $\begin{array}{l}\text { Relative Risk } \\
(95 \% \mathrm{Cl})\end{array}$ & $\mathrm{p}$ \\
\hline $\begin{array}{l}\text { Postoperative } \\
\text { hospital stay }\end{array}$ & & & & 25.482 & $\begin{array}{l}4.646(2.513- \\
8.588)\end{array}$ & $<0.001$ \\
\hline$\leq 28$ days & $130(63.7 \%)$ & $88(79.3 \%)$ & $42(45.2 \%)$ & & & \\
\hline$>28$ days & $74(36.3 \%)$ & $23(20.7 \%)$ & $51(54.8 \%)$ & & & \\
\hline $\begin{array}{l}\text { Occurrence of } \\
\text { complications } \\
d\end{array}$ & & & & 28.548 & $\begin{array}{l}4.926(2.699- \\
8.991)\end{array}$ & $<0.001$ \\
\hline Yes & $84(41.2 \%)$ & $27(24.3 \%)$ & $57(61.3 \%)$ & & & \\
\hline No & $120(58.8 \%)$ & $84(75.7 \%)$ & $36(38.7 \%)$ & & & \\
\hline
\end{tabular}


Table 3

Association between preoperative variables and postoperative hospital stay.

\begin{tabular}{|c|c|c|c|c|}
\hline & Totally & $\begin{array}{l}\text { Postoperative } \\
\text { hospital stay } \leq \\
\text { 28days }\end{array}$ & $\begin{array}{l}\text { Postoperative } \\
\text { hospital stay > } \\
\text { 28days }\end{array}$ & $\mathbf{P}$ \\
\hline Variable & $(n=204)$ & $(n=130)$ & $(n=74)$ & \\
\hline Gender & & & & 0.119 \\
\hline Male & $132(64.7 \%)$ & $79(60.8 \%)$ & $53(71.6 \%)$ & \\
\hline Feamale & $72(35.3 \%)$ & $51(39.2 \%)$ & $21(28.4 \%)$ & \\
\hline Gestational age(weeks) & $31.91 \pm 2.63$ & $32.54 \pm 2.61$ & $30.82 \pm 2.30$ & $\begin{array}{l}< \\
0.001\end{array}$ \\
\hline Gestational weight(g) & $\begin{array}{l}1725.15 \pm \\
550.03\end{array}$ & $1894.06 \pm 586.17$ & $1431.18 \pm 309.37$ & $\begin{array}{l}< \\
0.001\end{array}$ \\
\hline Type of delivery & & & & 0.668 \\
\hline caesarean delivery & $147(72.1 \%)$ & $95(73.1 \%)$ & $52(70.3 \%)$ & \\
\hline natural labour & $57(27.9 \%)$ & $35(26.9 \%)$ & $22(29.7 \%)$ & \\
\hline $\begin{array}{l}\text { Post-conceptual age } \\
\text { (weeks) }\end{array}$ & $36.01 \pm 3.65$ & $37.06 \pm 3.64$ & $34.16 \pm 2.87$ & $\begin{array}{l}< \\
0.001\end{array}$ \\
\hline Preoperative weight(g) & $\begin{array}{l}2003.02 \pm \\
510.05\end{array}$ & $2185.39 \pm 504.43$ & $1682.65 \pm 332.44$ & $\begin{array}{l}< \\
0.001\end{array}$ \\
\hline $\begin{array}{l}\text { Preoperative } \\
\text { hemoglobin(g/l) }\end{array}$ & $114.92 \pm 24.11$ & $113.35 \pm 19.99$ & $118.88 \pm 26.83$ & 0.125 \\
\hline $\begin{array}{l}\text { Preoperative albumin } \\
(\mathrm{g} / \mathrm{l})\end{array}$ & $29.46 \pm 4.65$ & $29.84 \pm 4.67$ & $28.79 \pm 4.57$ & 0.121 \\
\hline $\begin{array}{l}\text { Preoperative creatinine } \\
(\mathrm{g} / \mathrm{l})\end{array}$ & $47.85 \pm 15.67$ & $45.08 \pm 13.76$ & $52.70 \pm 17.63$ & 0.001 \\
\hline Preoperative CRP(mg/l) & $29.9(6.70,78.83)$ & $31.05(6.48,79.08)$ & $29.35(7.11,77.70)$ & 0.533 \\
\hline $\begin{array}{l}\text { Preoperative SBP } \\
\text { (mmhg) }\end{array}$ & $65.36 \pm 11.46$ & $65.55 \pm 11.33$ & $65.03 \pm 11.76$ & 0.757 \\
\hline $\begin{array}{l}\text { Preoperative DBP } \\
\text { (mmhg) }\end{array}$ & $35.06 \pm 8.65$ & $35.75 \pm 8.32$ & $33.85 \pm 9.14$ & 0.133 \\
\hline Preoperative HR (bmp) & $146.35 \pm 12.29$ & $146.13 \pm 12.34$ & $146.74 \pm 12.29$ & 0.733 \\
\hline $\begin{array}{l}\text { Preoperative inotrope } \\
\text { drugs }\end{array}$ & & & & 0.154 \\
\hline Yes & $39(19.1 \%)$ & $21(16.2 \%)$ & $18(24.3 \%)$ & \\
\hline No & 165(80.9\%) & 109(83.8\%) & $56(75.7 \%)$ & \\
\hline
\end{tabular}




\begin{tabular}{|lllll|}
\hline & Totally & $\begin{array}{l}\text { Postoperative } \\
\text { hospital stay } \leq \\
\text { 28days }\end{array}$ & $\begin{array}{l}\text { Postoperative } \\
\text { hospital stay } \\
\text { 28days }\end{array}$ & P \\
\hline $\begin{array}{l}\text { GDR one day before } \\
\text { surgery(mg/kg/min) }\end{array}$ & $6.83 \pm 0.96$ & $6.88 \pm 0.93$ & $6.74 \pm 1.02$ & 0.317 \\
\hline $\begin{array}{l}\text { GDR on the day of } \\
\text { surgery(mg/kg/min) }\end{array}$ & $6.59 \pm 1.19$ & $6.59 \pm 1.27$ & $6.59 \pm 1.06$ & 0.993 \\
\hline
\end{tabular}


Table 4

Association between intra-and postoperative variables and postoperative hospital stay.

\begin{tabular}{|c|c|c|c|c|}
\hline & Totally & $\begin{array}{l}\text { Postoperative hospital } \\
\text { stay } \leq 28 \text { days }\end{array}$ & $\begin{array}{l}\text { Postoperative hospital } \\
\text { stay >28days }\end{array}$ & $\mathbf{P}$ \\
\hline Variable & $(n=98)$ & $(n=130)$ & $(n=74)$ & \\
\hline ASA classification & & & & $\begin{array}{l}< \\
0.001\end{array}$ \\
\hline 2 and 3 & $136(66.7 \%)$ & $99(76.2 \%)$ & $37(50 \%)$ & \\
\hline 4 & 68(33.3\%) & $31(23.8 \%)$ & $37(50 \%)$ & \\
\hline $\begin{array}{l}\text { Entry into O.R. with } \\
\text { endotracheal tube }\end{array}$ & & & & $<0.001$ \\
\hline Yes & $80(39.2 \%)$ & $38(29.2 \%)$ & $42(56.8 \%)$ & \\
\hline No & $124(60.8 \%)$ & $92(70.8 \%)$ & $32(43.2 \%)$ & \\
\hline Duration of surgery (min) & $\begin{array}{l}89.00 \pm \\
26.87\end{array}$ & $89.89 \pm 28.17$ & $87.43 \pm 24.52$ & 0.531 \\
\hline $\begin{array}{l}\text { Duration of anesthesia } \\
\text { (min) }\end{array}$ & $\begin{array}{l}107.02 \pm \\
29.37\end{array}$ & $109.18 \pm 32.02$ & $103.22 \pm 23.75$ & 0.163 \\
\hline $\begin{array}{l}\text { Hemodynamic } \\
\text { fluctuations }\end{array}$ & & & & 0.024 \\
\hline Yes & $151(74 \%)$ & $103(79.2 \%)$ & $48(64.9 \%)$ & \\
\hline No & $53(26 \%)$ & $27(20.8 \%)$ & $26(35.1 \%)$ & \\
\hline Blood loss (ml) & $5(5,10)$ & $5(2.75,10)$ & $10(5,10)$ & $\begin{array}{l}< \\
0.001\end{array}$ \\
\hline Fluid balance (ml) & $20(18.5,40)$ & $20(20,40)$ & $20(15,40)$ & 0.236 \\
\hline $\begin{array}{l}\text { Perioperative blood } \\
\text { transfusion(ml) }\end{array}$ & $30(0,30)$ & $30(0,30)$ & $30(0,30)$ & 0.987 \\
\hline $\begin{array}{l}\text { Perioperative blood } \\
\text { transfusion }\end{array}$ & & & & 0.178 \\
\hline Yes & $134(65.7 \%)$ & $81(62.3 \%)$ & $53(71.6 \%)$ & \\
\hline No & $70(34.3 \%)$ & $49(37.7 \%)$ & $21(28.4 \%)$ & \\
\hline $\begin{array}{l}\text { Postoperative } \\
\text { hemoglobin(g/l) }\end{array}$ & $\begin{array}{l}104.77 \pm \\
14.43\end{array}$ & $105.77 \pm 13.44$ & $103.03 \pm 15.97$ & 0.193 \\
\hline $\begin{array}{l}\text { Postoperative albumin } \\
(\mathrm{g} / \mathrm{l})\end{array}$ & $\begin{array}{l}35.05 \pm \\
7.32\end{array}$ & $35.30 \pm 6.79$ & $34.60 \pm 8.21$ & 0.514 \\
\hline
\end{tabular}




\begin{tabular}{|lllll|}
\hline & Totally & $\begin{array}{l}\text { Postoperative hospital } \\
\text { stay } \leq 28 \text { days }\end{array}$ & $\begin{array}{l}\text { Postoperative hospital } \\
\text { stay >28days }\end{array}$ & P \\
\hline time at O.R.(min) & $15(10,20)$ & $15(10,20)$ & $12(10,20)$ & 0.861 \\
\hline time in ICU (days) & $4(3,7)$ & $4(2,5)$ & $7(4,12)$ & 0.001 \\
\hline $\begin{array}{l}\text { GDR one day after } \\
\text { surgery(mg/kg/min) }\end{array}$ & $7.06 \pm 0.93$ & $7.10 \pm 0.96$ & $7.00 \pm 0.89$ & 0.43 \\
\hline Antibiotic use (day) & $18.47 \pm$ & $13.99 \pm 4.41$ & $26.34 \pm 8.18$ & 0.001 \\
\hline $\begin{array}{l}\text { Occurrence of } \\
\text { complications }\end{array}$ & 8.48 & & & 0.001 \\
\hline Yes & $84(41.2 \%)$ & $32(24.6 \%)$ & $52(70.3 \%)$ & \\
\hline No & $120(58.8 \%)$ & $98(75.4 \%)$ & $22(29.7 \%)$ & 0.001 \\
\hline Well glycemic control & & & & \\
\hline Yes & & & $23(31.1 \%)$ & 0.026 \\
\hline No & $111(54.4 \%)$ & $88(67.7 \%)$ & $51(68.9 \%)$ & $<$ \\
\hline Glucose value & $93(45.6 \%)$ & $42(32.3 \%)$ & $108.63 \pm 16.43$ & 0.001 \\
\hline SD of BG & $105.29 \pm$ & $103.39 \pm 15.84$ & $40.26 \pm 10.17$ & \\
\hline
\end{tabular}


Table 5

Risk factors for a prolonged postoperative hospital stay.

\begin{tabular}{|c|c|c|c|c|c|c|}
\hline \multirow[t]{2}{*}{ Parameters } & \multicolumn{3}{|c|}{ Univariate Logistic model } & \multicolumn{3}{|c|}{ Multivariate Logistic model } \\
\hline & $\mathrm{OR}$ & $95 \% \mathrm{Cl}$ & $\mathrm{P}$ & OR & $95 \% \mathrm{Cl}$ & $P$ \\
\hline Large post-conceptual age (week) & 0.693 & $\begin{array}{l}0.602- \\
0.796\end{array}$ & $<.001$ & & & 0.489 \\
\hline High Preoperative weight(g) & 0.996 & $\begin{array}{l}0.995- \\
0.997\end{array}$ & $<.001$ & 0.995 & $\begin{array}{l}0.992- \\
0.997\end{array}$ & $\hat{0}_{0.001}$ \\
\hline High preoperative creatinine(g/l) & 1.032 & $\begin{array}{l}1.013- \\
1.052\end{array}$ & 0.001 & & & 0.669 \\
\hline Entry into O.R. with endotracheal tube & 3.178 & $\begin{array}{l}1.752- \\
5.763\end{array}$ & $<.001$ & & & 0.784 \\
\hline High ASA classification & 3.194 & $\begin{array}{l}1.738- \\
5.869\end{array}$ & $<.001$ & & & 0.934 \\
\hline Hemodynamic fluctuations & 2.066 & $\begin{array}{l}1.091- \\
3.912\end{array}$ & 0.026 & & & 0.568 \\
\hline Blood loss (ml) & 1.099 & $\begin{array}{l}1.036- \\
1.166\end{array}$ & 0.002 & & & 0.16 \\
\hline $\begin{array}{l}\text { Long duration of tracheal extubation } \\
\text { (days) }\end{array}$ & 1.272 & $\begin{array}{l}1.137- \\
1.424\end{array}$ & $<.001$ & 1.239 & $\begin{array}{l}1.016- \\
1.512\end{array}$ & 0.035 \\
\hline Well glycemic control & 0.215 & $\begin{array}{l}0.116- \\
0.398\end{array}$ & $<.001$ & 0.129 & $\begin{array}{l}0.031- \\
0.535\end{array}$ & 0.005 \\
\hline High SD of BG & 1.060 & $\begin{array}{l}1.027- \\
1.093\end{array}$ & $<.001$ & & & 0.536 \\
\hline Long days of Antibiotics use (days) & 1.436 & $\begin{array}{l}1.294- \\
1.593\end{array}$ & $<.001$ & 1.421 & $\begin{array}{l}1.233- \\
1.637\end{array}$ & $<.001$ \\
\hline Occurrence of complication & 7.239 & $\begin{array}{l}3.822- \\
13.708\end{array}$ & $<.001$ & & & 0.695 \\
\hline
\end{tabular}

Figures 


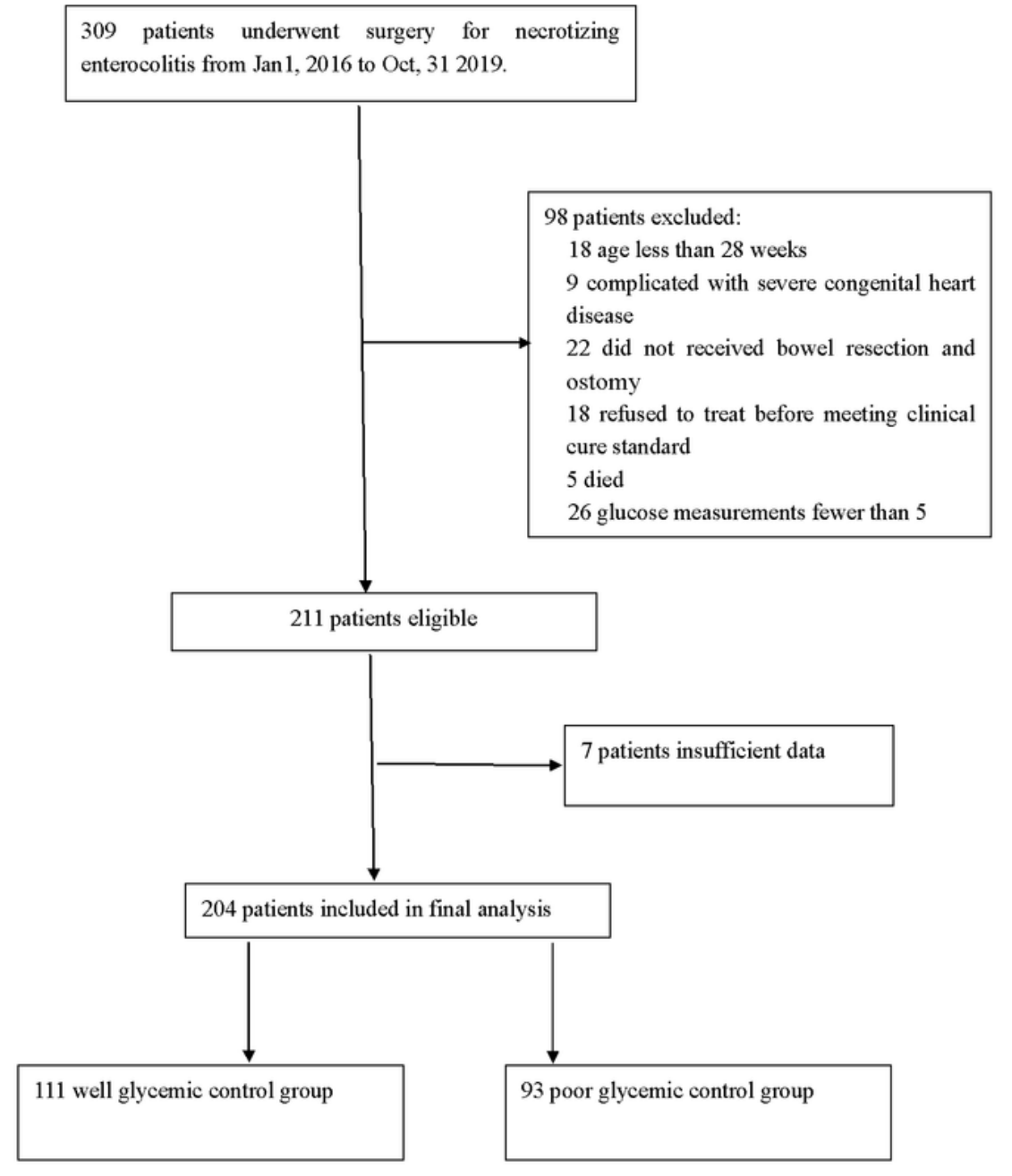

Figure 1

Flowchart of the study 